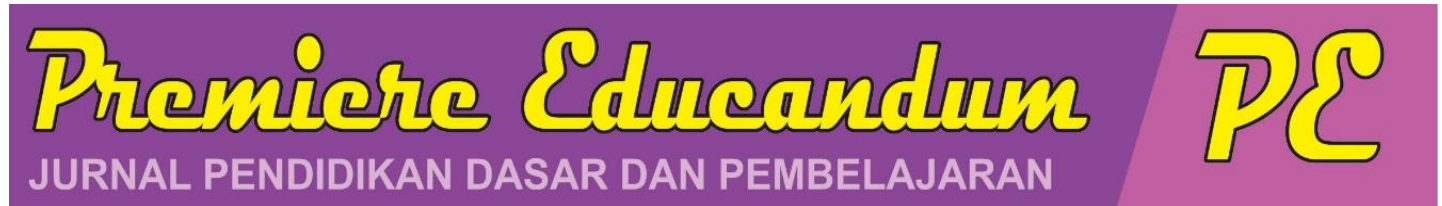

Premiere Educandum: Jurnal Pendidikan Dasar dan Pembelajaran

Volume 8(2) 127 - 139 Desember 2018

Copyright (C2018 Universitas PGRI Madiun

ISSN: 2088-5350 (Print) / ISSN: 2528-5173 (Online)

Available at: http://e-journal.unipma.ac.id/index.php/PE

Doi: 10.25273/pe.v8i2.2905

\title{
Pengaruh model brain based learning terhadap kemampuan komunikasi matematis siswa ditinjau dari kreativitas
}

\author{
Adi Apriadi Adiansha' ${ }^{1)}$, Muhamad Syarif Sumantri' ${ }^{2)}$, Makmuri $^{3)}$ \\ ${ }^{1}$ Program Studi Pendidikan Guru SD, STKIP Taman Siswa Bima, Indonesia \\ email: adiapriadiadiansyah@gmail.com \\ ${ }^{2}$ Program Studi Pascasarjana Pendidikan Dasar, Universitas Negeri Jakarta, Indonesia \\ email: mohamadsumantri@gmail.com \\ ${ }^{3}$ Fakultas MIPA, Universitas Negeri Jakarta, Indonesia \\ email: makmuri@unj.ac.id
}

\begin{abstract}
This study aims to determine the effect of Brain-Based Learning Model on students' mathematical communication abilities in terms of creativity. The research was conducted at SDN Pantai Harapan Jaya 01 Kecamatan Muara Gembong, using experimental research design treatment by level $2 \times 2$. The results showed that (1) Mathematical communication ability of students who were given treatment of Brain-Based Learning Model was higher compared to students using model Expository, (2) There is interaction of learning model with creativity to students' mathematical communication ability, (3) Mathematical communication ability given by Brain-Based Learning Model is higher compared to students given expository model treatment on students who have high creativity, and (4) The mathematical communication capability is given by the Brain-Based Learning Model is lower than that of the students given expository model treatment on students who have low creativity.
\end{abstract}

Keywords: Brain Based Learning, Creativity, Mathematical Communication

\section{Abstrak}

Penelitian ini bertujuan untuk mengetahui pengaruh model Brain Based Learning terhadap kemampuan komunikasi matematis yang ditinjau dari kreativitas. Penelitian dilaksanakan di SDN Pantai Harapan Jaya 01 Kecamatan Muara Gembong, dengan menggunakan penelitian eksperimen desain treatment by level $2 \times 2$. Hasil penelitian menunjukkan hasil bahwa; 1) Kemampuan komunikasi matematis siswa yang diberikan perlakukan model Brain Based Learning, 2) Terdapat interaksi model pembelajaran terhadap kemampuan komunikasi matematis ditinjau dari kreativitas, 3) Kemampuan komunikasi matematis yang diberikan perlakuan model Brain Based Learning lebih tinggi dibandingkan dengan siswa yang diberikan perlakuan model Ekspositori pada siswa yang memiliki kreativitas tinggi, dan 4) Kemampuan komunikasi matematis yang diberikan perlakuan model Brain Based Learning lebih rendah dibandingkan dengan siswa yang diberikan perlakuan model Ekspositori pada siswa yang memiliki kreativitas rendah.

Kata Kunci: Brain Based Learning, Kreativitas, Komunikasi Matematis

Histori artikel : disubmit pada 11 Agustus 2018; direvisi pada 10 Oktober 2018; diterima pada 20

Oktober 2018 


\section{A. PENDAHULUAN}

Matematika merupakan ilmu yang sangat penting dalam dunia kehidupan sehingga menjadikan matematika sebagai pembelajaran yang wajib dari setiap jenjang pendidikan yaitu SD/MI, SMP/MTs, SMA/MA bahkan sampai pada PTN/PTS. Menurut Polya menyebutkan bahwa fungsi matematika sebagai know-how (Syafri, 2015). Sedangkan menurut Byers menyatakan fungsi matematika sebagai a way of knowin (Syafri, 2015). Kedua para ahli tersebut mengatakan bahwa matematika berfungsi untuk membantu manusia dalam menyelesaikan masalah dengan menggunakan proses berfikir yang realistik.

Pembelajaran matematika Sekolah Dasar merupakan sesuatu pembelajaran yang sangat bermanfaat bagi pengetahuan anak tentang adanya perbedaan karakteristik terutama pada hakikat matematika dan hakekat anak, dengan hal tersebut diperlukan adanya jembatan yang bisa dapat membedakan perbedaan tersebut. Menurut Ruseffendi menjelsakan bahwa matematika yaitu bahasa simbol, dengan ilmu yang deduktif dengan tidak menerima

Tabel 1 Hasil PISA (Program for International Student Assesment) Tahun 2015

\begin{tabular}{|c|c|c|c|c|c|c|c|c|c|}
\hline \multirow[t]{3}{*}{ No } & \multirow[t]{3}{*}{ OECD Average } & \multicolumn{2}{|c|}{ Science } & \multicolumn{2}{|c|}{ Reading } & \multicolumn{2}{|c|}{ Mathematics } & \multicolumn{2}{|c|}{$\begin{array}{c}\text { Science, Reading, and } \\
\text { Mathematics }\end{array}$} \\
\hline & & $\begin{array}{l}\text { Mean } \\
\text { Score in } \\
\text { PISA } \\
2015\end{array}$ & $\begin{array}{c}\text { Average } \\
\text { three- } \\
\text { year } \\
\text { trend }\end{array}$ & $\begin{array}{c}\text { Mean } \\
\text { Score } \\
\text { in } \\
\text { PISA } \\
2015\end{array}$ & $\begin{array}{c}\text { Average } \\
\text { three- } \\
\text { year } \\
\text { trend }\end{array}$ & $\begin{array}{c}\text { Mean } \\
\text { Score } \\
\text { in } \\
\text { PISA } \\
2015\end{array}$ & $\begin{array}{c}\text { Average } \\
\text { three- } \\
\text { year } \\
\text { trend }\end{array}$ & $\begin{array}{c}\text { Share of Top } \\
\text { Permormance } \\
\text { In at Least } \\
\text { One Subject } \\
\text { (Level } 5 \text { or 6) }\end{array}$ & $\begin{array}{c}\text { Share Of } \\
\text { Low } \\
\text { Achievers } \\
\text { in All } \\
\text { Three } \\
\text { Subject } \\
\text { (Below } \\
\text { Level 2) } \\
\end{array}$ \\
\hline & & Mean & Score dif & Mean & Score dif & Mean & Score dif & $\%$ & $\%$ \\
\hline 1 & Singapore & 556 & 7 & 535 & 5 & 564 & 1 & 39.1 & 4.8 \\
\hline 2 & Japan & 538 & 3 & 516 & -2 & 532 & 1 & 25.8 & 5.6 \\
\hline 3 & Estonia & 534 & 2 & 519 & 9 & 520 & 2 & 20.4 & 4.7 \\
\hline 4 & Chinese Taipei & 532 & 0 & 497 & 1 & 542 & 0 & 29.9 & 8.3 \\
\hline 5 & Finland & 531 & -11 & 526 & -5 & 511 & -10 & 21.4 & 6.3 \\
\hline 62 & Indonesia & 403 & 3 & 397 & -2 & 386 & 4 & 0.8 & 42.3 \\
\hline 70 & Dominican Republic & 332 & $\mathrm{M}$ & 358 & $\mathrm{~m}$ & 328 & $\mathrm{~m}$ & 0.1 & 70.7 \\
\hline
\end{tabular}

Sumber: OECD 2016 (Indonesia, Nation, Goals, Indonesia, \& Nam, 2016; PISA, 2016) pembuktian secara induktif, ilmunya tentang pola keteraturan, struktur yang terorganisi, mulai dari bagian yang tidak didefinisikan sampai dengan unsur yang akan didefinisikan, dari aksioma atau postulat dan akhirnya ke dalil. (Heruman, 2012).

Fakta keadaan siswa dalam proses pembelajaran lebih cenderung dalam menghafat konsep pada pembelajaran matematika tanpa memahami bagianbagian dalam menyelesaikan masalah matematika. Apalagi dalam proses pembelajaran siswa menerima konsep matematika yang salah maka siswa sangat susah dalam memperbaiki kembali dalam menyelesaikan permasalahan pada soal-soal matematika. Pada kenyataan selanjutnya, yaitu tujuan ketercapaian dalam hasil pembelajaran matematika masih jauh dari kenyataan, hal ini dibuktikan dengan belum adanya data atau bukti bahwa hasil pembelajaran matematika di Negera Indonesia terbaik pertama pada kanca internasional. Hasil laporan PISA tahun 2015 dengan Negara peserta yang ikut sebaganyak 70 Negera, yaitu dapat dilihat pada Tabel 1 di bawah ini: 
Berdasarkan pada Tabel 1, menujukkan bahwa peserta Indonesia menduduki rengking 62 dari 70 Negara peserta yang ikut dengan rerata hasil kompetensi pada pembelajaran matematika yaitu 489 . Hal tersebut menunjukkan bahwa dari ketiga kompetensi tersebut nilai ratarata yang didapat negara Indonesia paling kecil yaitu pada pembelajaran matematika. Selain dari itu jsuga negara Indonesia menduduki pada peringkat yang rendah dan jauh sekali dari negara-negara yang lainnya. Hal ini sesuai dai hasi laporan TIMSS Tahun 2015 dari sumber International Association for the Evaluation of Educational Achievement (Adiansha \& Sumantri, 2017; NCES, 2017), bahwa Indonesia berada pada posisi ke 44 dari 56 Negara peserta yang ikut dengan skor rerata sebesar 397 dari 500. Dengan demikian, bahwa hasil pembelajaran matematika di Negara Indoesia belum mencapai hasil yang memuaskan, atau baik.

Dari masalah di atas, dipilih kemampuan komunikasi matematis untuk ditingkatkan di jenjang pendidikan dasar, karena komunikasi matematis dalam pembelajaran matematika merupakan salah satu yang sangat diperlukan dalam pembelajaran bagi siswa agar konsep yang dipelajari mudah untuk dipahami. Dalam Permendiknas Nomor 22 Tahun 2006 dengan standar isi yaitu harus memiliki kemampuan dalam memahami konsep pembelajaran pada matematika, selalu menggunakan dalam penalaran, selalu mengkomunikasikan gagasan dan selalu memiliki siswa yang saling menghargai dalam proses kehidupan (Kebudayaan, 2016; Permendikbud, 2016; Zaini \& Marsigit, 2014).

Pembelajaran matematika

merupakan sesuatu kegiatan pembelajaran sehingga siswa memperoleh ilmu pengetahuan, kemampuan, dan keterampilan dalam menyelesaikan permasalah matematika. Berdasarkan observasi awal SDN Pantai Harapan Jaya 01 Bekasi pada mata pelajaran matematika, tingkat komunikasi dalam proses pembelajaran masih sangat kurang, misalnya kurangnya siswa dalam menyampaikan ide dan gagasan dalam pembelajaran matematika, siswa belum mampu menggunakan simbol-simbol, lambang matematika dengan tepat.

Instrumen tes diberikan kepada siswa untuk bisa mengetahui tingkat kemampuan siswa dalam pembelajaran matematika, khususnya pada aspek komunikasi matematis. Sehingga ditemukan hasil gejala komunikasi matematis yang rendah pada siswa tersebut. Gejala-gejala tersebut yaitu 1) $60 \%$ dari jumlah siswa tidak bisa mengkrontrusikan persoalan matematika kedalam bentuk grafik atau gambar, 2) $65 \%$ dari jumlah siswa tidak bisa menggunakan simbol-simbol matematika dalam menyelesaikan persoalan matematika, 3) $81 \%$ dari jumlah siswa tidak bisa menyampaikan argumen terhadap ide matematika yang dimilikinya, 4) 69\% dari jumlah siswa tidak bisa mendeskripsikan langkah-langkah pengerjaan soal dalam pembelajaran 
matematika, dan 5) 50\% dari jumlah siswa tidak bisa mengambil kesimpulan dari pemecahan soal matematika.

National Council of Teachers of Mathematics (NCTM) menjelaskan bahwa kemampuan komunikasi matematis merupakan suatu metode bagi siswa dalam mengartikulasikan, menjelaskan, mengkonsolidasikan, dan mengatut pemekiran positif matematis yang merreka miliki (Abdur Rahman As'ari, 2016; Cai, J., Jakabcsin, M. S., Lane, n.d.; Cockburn, 2007; Cooke, B. D., n.d.). Sedangkan Cooke dan Buchholz mengatakan bahwa komunikasi matematis yaitu suatu proses dalam menyampaikan gagasan, pesan, serta mampu meningkatkan asimilasi dalam pembelajaran matematis ke konteks yang baru (Abdur Rahman As'ari, 2016; Schneider, E. \& Peschek, 2002). Namun, berdasarkan beberapa peneliti dalam temuanya menjelaskan bahwa kemampuan komunikasi matematis adalah kemampuan untuk memahami simbol, ide, struktur, diagram, angka, tabel dan kalimat matematika untuk selanjutnya menggunakannya dalam pemecahan masalah dan mengungkapkannya kembali dalam pembelajaran matematika di kelas (Ahmad Susanto, 2013; Maulani, D., Suyono, Noornia, 2017; Miranda, Cilvia, \& Rahman, 2015). Berdasarkan pendapat tersebut bahwa dalam mengukur kemampuan komunikasi matematis dalam penelitian ini adalah a) Siswa mengkrontrusikan persoalan matematika kedalam bentuk grafik atau gambar, b) Siswa menggunakan simbol-simbol matematika dalam menyelesaikan persoalan matematika, c) Siswa menyampaikan argumen terhadap ide matematika yang dimilikinya, c) Siswa mendeskripsikan langkah-langkah pengerjaan soal dalam pembelajaran matematika, d) Siswa mengambil kesimpulan dari pemecahan soal matematika.

Melihat pentingnya kemampuan komunikasi matematis dalam pembelajaran matematika, maka dalam kegiatan proses pembelajaran di dalam kelas harus dimaksimalkan. Dalam memaksimalkan kemampuan komunikasi matematis dalam proses pembelajaran digunakan model pembelajarab Brain Based Learning sebagai alternatif. Jensen mengatakan Brain Based Learning merupakan pembelajaran yang diselaraskan dengan cara kerja otak yang didesain secara alamiah untuk belajar sehingga diharapkan pembelajaran dapat diserap oleh otak secara optimal. Brain Based Learning mampu menciptakan keputusan yang lebih baik, dan tidak dapat menjangkau lebih banyak pembelajar, lebih sering dan tingkat kesalahan lebih kecil (Jensen, 2007; Waree, 2017b).

Sedangkan beberapa peneliti menjelaskan bahwa Brain Based Learning merupakan pembelajaran yang diselaraskan dengan cara kerja otak yang didesain secara ilmiah untuk belajar, tidak terfokus terhadap keterurutan, tetapi lebih mengutamakan pada kesenangan dan kecintaan siswa akan belajar sehingga siswa dapat dengan mudah menyerap materi yang sedang dipelajari (A. AlBalushi \& Al-Balushi, 2018; Adiansha 
\& Sumantri, 2017; Connell, 2009; Duman, 2010; Gladys, Stella, \& Omobolanle, 2018; GÖZÜYEŞİL \& DİKİCI, 2014; Kartikaningtyas, A Kusmayadi, \& Riyadi, 2018; Ningsih, 2017; Ozturk, 2018; Waree, 2017a; Widiana, Bayu, \& Jayanta, 2017; Yasar, 2017; Yulvinamaesari, 2014).

Dalam pembelajaran dengan menggunakan Model Brain Based Learning dipengaruhi oleh kreativitas dikarenakan siswa memperoleh konsep dan pengetahuan secara langsung melalui interaksi dengan teman sejawat sehingga melahirkan ide dan gagasan yang baru dalam diskusi materi yang belum pernah dipelajari sebelumnya. Mengingat kemampuan komunikasi matematis yang dimiliki siswa dapat dipengaruhi oleh kreativitas yang dimiliki siswa. Kreativitas sebagai kemampuan mencerminkan kelancaran, keluwesan dan orisinalitas berpikir serta kemampuan elaborasi (mengembangkan, memperkaya, memerinci) suatu gagasan. Kreativitas adalah kunci untuk meraih keberhasilan dalam memecahkan masalah. Kreativitaslah yang menjembatani antara tahap pengelolaan kognisi dan tahap eksekusi agar seseorang memeiliki prestasi dan hasil yang menyakinkan. Kreativitas merupakan kemampuan untuk berkerja dan menghasilkan sesuatu yang baru (orisinal, tidak terbayangkan sebelumnya) dan tepat (bermanfaat, memenuhi tujuan kerja yang dihararapkan). Kreativitas mengacu antara lain pada kemampuan menghasilkan berbagai kemungkinan, ide-ide baru, asli, pemikiran yang mencerminkan wawasan, rasa ingin tahu, dan kemampuan mengidentifikasi hubungan antara konsep atau gagasan.

Berdasarkan uraian di atas, maka terdapat pengaruh antara kreativitas siswa terhadap kemampuan komunikasi matematis melalui Model Brain Based Learning. Sehingga berkeinginan untuk melakukan penelitian berjudul "Pengaruh Model Brain Based Learning terhadap Kemampuan Komunikasi Matematis ditinjau dari Kreativitas Siswa Kelas IV SDN Pantai Harapan Jaya 01 Bekasi.

Rumusan Masalah yang digunakan dalam penelitian ini yaitu 1) Apakah terdapat perbedaan kemampuan komunikasi matematis siswa yang menggunakan Model Brain Based Learning dengan siswa kelas yang menggunakan Model Ekspositori?; 2) Apakah terdapat interaksi antara Model pembelajaran dan kreativitas terhadap kemampuan komunikasi matematis siswa?; 3) Apakah terdapat perbedaan kemampuan komunikasi matematis antara siswa yang belajar dengan Model Brain Based Learning dan siswa yang belajar dengan Model Ekspositori pada siswa yang memiliki kreativitas tinggi?; 4) Apakah terdapat perbedaan kemampuan komunikasi matematis antara siswa yang belajar dengan Model Brain Based Learning dan siswa yang belajar dengan Model Ekspositori pada siswa yang memiliki kreativitas rendah?

Tujuan yang telah dicapai dalam penelitian ini yaitu 1) Menjelaskan perbedaan kemampuan komunikasi 
matematis siswa yang menggunakan Model Brain Based Learning dengan siswa kelas yang menggunakan Model Ekspositori; 2) Menjelaskan interaksi antara Model pembelajaran dan kreativitas terhadap kemampuan komunikasi matematis siswa; 3) Menjelaskan perbedaan kemampuan komunikasi matematis antara siswa yang belajar dengan Model Brain Based Learning dan siswa yang belajar dengan Model Ekspositori pada siswa yang memiliki kreativitas tinggi; 4) Menjelaskan perbedaan kemampuan komunikasi matematis antara siswa yang belajar dengan Model Brain Based Learning dan siswa yang belajar dengan Model Ekspositori pada siswa yang memiliki kreativitas rendah

\section{B. METODE}

Dalam Penelitian ini metode yang digunakan dalam mengukur hasil kemampuan komunikasi matemas siswa yaitu metode eksperimen dengan treatment by level $2 \times 2$. Dengan desain penelitian, seperti pada tabel 2 sebagai berikut:

Tabel 2 Rancangan Penelitian Eksperimen

\begin{tabular}{ccc}
\hline \multirow{2}{*}{$\begin{array}{c}\text { Variabel Atribut } \\
\text { Kreativitas (B) }\end{array}$} & \multicolumn{2}{c}{ Variabel Perlakuan (A) } \\
\cline { 2 - 3 } & Brain Based Learning & Ekspositori \\
& $(\mathrm{A} 1)$ & $\mathrm{A}_{2} \mathrm{~B}_{1}$ \\
\hline Kreativitas Tinggi $\left(\mathrm{B}_{1}\right)$ & $\mathrm{A}_{1} \mathrm{~B}_{1}$ & $\mathrm{~A}_{2} \mathrm{~B}_{2}$ \\
\hline Kreativitas Rendah $\left(\mathrm{B}_{2}\right)$ & $\mathrm{A}_{1} \mathrm{~B}_{2}$ & \\
\hline
\end{tabular}

Subjek penelitian ini adalah siswa kelas IV di SDN 01 Pantai Harapan Jaya Bekasi dengan jumlah untuk kelas eksperimen sebanyak 30 siswa dan untuk kelas kontrol sebanyak 28 siswa. Rata-rata usia siswa pada kelas eksperimen dan kelas kontrol yaitu \pm 9 tahun. Dimana pada kelas eksperimen dan kontrol rata-rata memiliki latarbelakang sosial memiliki kehidupan berkecukupan dengan orang tuanya kebanyakan berstatus nelayan dan pertanian dan sekitar 6 orang tiap kelas orang tuanya berstatus PNS. Rata-rata kemampuan setelah dilakukan tes uji coba hampir memiliki kemampuan yang sama dari kedua kelas tersebut.

Prosedur pelaksanaan pada penelitian seperti pada tabel 2, yaitu dengan disain yang digunakan treatmen by level $2 \times 2$. Dimana pada kelas eksperimen akan menggunakan model Brain Based Learning sedangkan pada kelas kontrol dengan menggunakan pembelajaran ekspositori. Pada variabel Metode Brain Based Leaning dan Pembelajaran ekspositori masingmasing akan ditinjau dari kreativitas yang dimiliki siswa sehingga pada siswa akan ditemukan siswa yang memiliki kreativitas tinggi dan kreativitas rendah.

Selanjutnya, setelah siswa diberikan tes kreativitas maka akan diambil sebagai hasil analisis data pada siswa yang memiliki kreativitas tinggi pada skor rentang sebesar 33\% dan siswa yang memiliki kreativitas rendah pada skor rentang 33\% juga. Sehingga akan di dapat pada kelas 
eksperimen yaitu siswa yang menggunakan model Brain Based Leaning dengan kreativitas tinggi $\left(\mathrm{A}_{1} \mathrm{~B}_{1}\right)$ sebanyak 10 siswa, dan siswa yang menggunakan model Brain Based Leaning dengan kreativitas rendah $\left(\mathrm{A}_{1} \mathrm{~B}_{2}\right)$ sebanyak 10 siswa. Kemudian pada kelas kontrol yaitu siswa yang menggunakan pembelajaran ekspositori dengan kreativitas tinggi $\left(\mathrm{A}_{2} \mathrm{~B}_{1}\right)$ sebanyak 10 siswa, dan siswa yang menggunakan pembelajaran ekspositori dengan kreativitas rendah $\left(\mathrm{A}_{2} \mathrm{~B}_{2}\right)$ sebanyak 10 siswa.

Teknik pengambilan sampel dilakukan dengan proses sebagai berikut: 1) Memilih secara acak SDN di kecamatan Muara Gembong Kabupaten Bekasi dan terpilih SDN
01 Pantai harapan Jaya, 2) Kemudian menentukan kelas eksperimen dan kelas kontrol, sehingga terpilih siswa kelas IVA sebagai kelas eksperimen dan kelas IVB sebagai kelas kontrol. Teknik pengumpulan data pada variabel kreativitas dan kemampuan komunikasi matematis siswa yaitu menggunakan tes essay dengan masing-masing 5 soal.

\section{HASIL DAN PEMBAHASAN \\ 1. Deskripsi Data}

Setelah mengikuti proses pembelajaran dengan menggunaka Model Brain Based Learning dan Model Ekspositori, maka diperoleh hasil kemampuan komunikasi matematis siswa berupa skor.

Tabel 3 Deskripsi Kemampuan Komunikasi Matematis Siswa

\begin{tabular}{lcccccccccc}
\hline & \multicolumn{4}{c}{ Brain Based Learning } & \multicolumn{5}{c}{ Model Ekspositori } \\
\cline { 2 - 11 } Kreativitas & $\mathrm{N}$ & Max & Min & $\begin{array}{c}\text { Rata- } \\
\text { Rata }\end{array}$ & SD & N & Max & Min & $\begin{array}{c}\text { Rata- } \\
\text { Rata }\end{array}$ & SD \\
\hline Tinggi & 10 & 80 & 60 & 71.5 & 6.69 & 10 & 70 & 45 & 54.5 & 8.32 \\
\hline Rendah & 10 & 70 & 50 & 60.5 & 5.99 & 10 & 70 & 40 & 60 & 9.43 \\
\hline$\sum$ & 20 & 80 & 50 & 66 & 8.37 & 20 & 70 & 40 & 57.25 & 9.1 \\
\hline
\end{tabular}

2. Pengujian Persyaratan Analisis

a. Uji Normalitas dan Homogenitas Kelompok Siswa yang Menggunakan Model Brain Based Learning dan Model Ekspositori

Berdasarkan hasil analisis uji normalitas pada kelompok siswa yang menggunakan model Brain Based Learnig dan Model Ekspositori dengan menggunakan SPSS Versi 24, maka memperlihatkan nilai signifikansi data kemampuan komunikasi matematis siswa pada kelompok siswa yang menggunakan model Brain Based Learning menunjukkan KolmogororovSmimov $^{4}$ sebesar $0.200>0,05$, Kemudian Shapiro-Wilk menunjukkan bahwa nilai signifikan $0.530>0,05$. Kemudian pada model Ekspositori menunjukkan KolmogororovSmimov $^{4}$ sebesar $0.200>0,05$, Kemudian Shapiro-Wilk menunjukkan bahwa nilai signifikan $0.236>0,05$. Hal tersebut berarti bahwa data nilai komunikasi matematis dari 20 sampel siswa yang diberikan perlakuan dengan Model Brain Based Learning 
dan Model Ekspositori berdistribusi normal.

Kemudian, berdasarkan hasil analisis uji homogenitas pada kelompok siswa yang menggunakan model Brain Based Learning dan Model Ekspositori dengan menggunakan SPSS Versi 24, maka memperlihatkan bahwa Levence Statistic dengan Signifikan 0, 475 > 0,05 yang berarti data nilai kemampuan komunikasi matematis memiliki Test of Homogeneity of Variances yang homogen.

b. Uji Normalitas dan Homogenitas Kelompok Siswa Model Brain Based Learning dan Pembelajaran Ekpositori Pada Siswa yang Memiliki Kreativitas Tinggi

Berdasarkan hasil analisis uji normalitas pada kelompok siswa yang menggunakan model Brain Based Learnig dan Model Ekspositori pada siswa yang memiliki kreativitas tinggi dengan menggunakan SPSS Versi 24, maka memperlihatkan nilai signifikansi data kemampuan komunikasi matematis siswa pada kelompok siswa yang menggunakan model Brain Based Learning dengan kreativitas tinggi menunjukkan Kolmogororov-Smimov ${ }^{4}$ sebesar $0.200>0,05$, Kemudian Shapiro-Wilk menunjukkan bahwa nilai signifikan $0,466>0,05$. Kemudian pada model Ekspositori dengan kreativitas tinggi menunjukkan KolmogororovSmimov $^{4}$ sebesar $0.200>0,05$, Kemudian Shapiro-Wilk menunjukkan bahwa nilai signifikan $0.325>0,05$. Hal tersebut berarti bahwa data nilai komunikasi matematis dari 10 sampel siswa yang diberikan perlakuan dengan Model Brain Based Learning dan Model Ekspositori pada siswa yang memiliki kreativitas tinggi yaitu berdistribusi normal.

Kemudian, berdasarkan hasil analisis uji homogenitas pada kelompok siswa yang menggunakan model Brain Based Learning dan Model Ekspositori pada siswa yang memiliki kreativitas tinggi dengan menggunakan SPSS Versi 24, maka memperlihatkan bahwa Levence Statistic dengan Signifikan 0,591> 0,05 yang berarti data nilai kemampuan komunikasi matematis memiliki Test of Homogeneity of Variances yang homogen.

c. Uji Normalitas dan Homogenitas Kelompok Siswa Model Brain Based Learning dan Model Ekspositori Pada Siswa yang Memiliki Kreativitas Rendah

Berdasarkan hasil analisis uji normalitas pada kelompok siswa yang menggunakan model Brain Based Learnig dan Model Ekspositori pada siswa yang memiliki kreativitas rendah dengan menggunakan SPSS Versi 24, maka memperlihatkan nilai signifikansi data kemampuan komunikasi matematis siswa pada kelompok siswa yang menggunakan model Brain Based Learning dengan kreativitas rendah menunjukkan Kolmogororov-Smimov ${ }^{4}$ sebesar $0.200>0,05$, Kemudian Shapiro-Wilk menunjukkan bahwa nilai signifikan $0,691>0,05$. Kemudian pada model Ekspositori dengan kreativitas rendah menunjukkan KolmogororovSmimov $^{4}$ sebesar $0.200>0,05$, Kemudian Shapiro-Wilk menunjukkan bahwa nilai signifikan $0.190>0,05$. 
Hal tersebut berarti bahwa data nilai komunikasi matematis dari 10 sampel siswa yang diberikan perlakuan dengan Model Brain Based Learning dan Model Ekspositori pada siswa yang memiliki kreativitas rendah yaitu berdistribusi normal.

Kemudian, berdasarkan hasil analisis uji homogenitas pada kelompok siswa yang menggunakan model Brain Based Learning dan Model Ekspositori pada siswa yang memiliki kreativitas rendah dengan menggunakan SPSS Versi 24, maka memperlihatkan bahwa Levence Statistic dengan Signifikan 0,282 > 0,05 yang berarti data nilai kemampuan komunikasi matematis memiliki Test of Homogeneity of Variances yang homogen.

\section{Pengujian Hipotesis}

a. Kemampuan Komunikasi Metamatis Siswa yang mendapatkan Perlakuan Model Brain Based Learning Lebih Tinggi pada Siswa yang Mendapatkan Perlakuan Model Ekspositori.

Berdasarkan hasil uji hipotesis dengan menggunakan analisis ANAVA dua jalur yang menunjukkan bahwa siswa yang diberikan perlakuan Model Brain Based Learning dan Model Ekspositori memperoleh nilai $F_{\text {hitung }}$ sebesar 12.84. Dengan taraf signifikani 0.05 dengan $\mathrm{df}_{1}=2 \mathrm{dan}_{\mathrm{df}}$ $=18$, maka bila dilihat dari $F_{\text {tabel }}$ diperoleh nilai $\mathrm{F}_{\text {tabel }}=3.55$.

Dengan demikian, bahwa nilai $F_{\text {hitung }}=12.84>$ nilai $F_{\text {tabel }}=3.55$, hal ini berarti terjadi penolakan $\mathrm{H}_{0}$ yang artinya ada perbedaan nilai kemampuan komunikasi matematis antara kedua kelompok siswa yang diberikan pembelajaran berbeda. Selain itu adanya penerimaan $\mathrm{H}_{1}$ berarti kemampuan komunikasi matematis kelompok siswa yang diberikan perlakuan Model Brain Based Learning lebih tinggi dibandingkan kelompok siswa yang diberikan Model Ekspositori.

b. Interaksi antara Model Pembelajaran dan kreativitas terhadap kemampuan komunikasi matematis siswa.

Berdasarkan hasil analisis dengan menggunakan SPSS Versi 24 maka terdapat interaksi antara model pembelajaran yaitu model Brain Based Learning dan model ekspositori dengan kreativitas terhadap kemampuan komunikasi matematis. Hal ini menunjukkan melalui kolom interaksi pembelajaran dengan kreativitas diperoleh nilai signifikan sebesar $0.002<0.05$ dengan taraf signifikan 0.05 . Hal ini berarti bahwa terdapat interaksi yang signifikan antara pembelajaran yang digunakan dengan kreativitas terhadap kemampuan komunikasi matematis.

c. Perbedaan

Kemampuan

Komunikasi Matematis Siswa yang Mendapat Perlakuan Model Brain Based Learning dan Model Ekspositori untuk Siswa yang Memiliki Kreativitas Tinggi.

Berdasarkan hasil analisis dengan uji-t dengan menggunakan SPSS Versi 24 bahwa siswa yang diberikan perlakuan dengan Model Brain Based Learning dengan kreativitas tinggi dan Model Ekspositori dengan kreativitas tinggi memperoleh nilai $t_{\text {hitung }}$ sebesar 5.04. 
Dengan taraf signifikansi 0.05 dan derajat kebesaran 18 maka bila dilihat pada tabel $\mathrm{t}$ diperoleh $\mathrm{t}_{\text {tabel }}$ sebesar 2.10. Dengan demikian, bahwa nilai $t_{\text {hitung }}=5.04>$ nilai $t_{\text {tabel }}=2.10$, hal ini berarti terjadi penolakan $\mathrm{H}_{0}$ yang berarti ada perbedaan nilai kemampuan komunikasi matematis antara siswa yang menggunakan perlakuan pembelajaran yang berbeda walaupun sama-sama memiliki kreativitas tinggi. Selain itu adanya penerimaan $\mathrm{H}_{1}$ berarti lemampuan komunikasi matematis siswa yang diberikan perlakuan dengan menggunakan Model Brain Based Learning lebih tinggi dibandingkan siswa yang menggunakan perlakuan Model Ekspositori yang sama-sama memiliki kreativitas tinggi.

d. Perbedaan

Kemampuan

Komunikasi Matematis Siswa yang Mendapat Perlakuan Model Brain Based Learning dan Model Ekspositori untuk Siswa yang Memiliki Kreativitas Rendah.

Berdasarkan hasil analisis dengan uji-t dengan menggunakan SPSS Versi 24 menunjukkan bahwa hasil analisis dengan uji-t yaitu bahwa siswa yang diberikan perlakuan dengan Model Brain Based Learning dengan kreativitas rendah dan Model Ekspositori dengan kreativitas rendah memperoleh nilai $t_{\text {hitung }}$ sebesar 1.42. Dengan taraf signifikansi 0.05 dan derajat kebesaran 18 maka bila dilihat pada tabel $\mathrm{t}$ diperoleh $\mathrm{t}_{\text {tabel }}$ sebesar 2.10. Dengan demikian, bahwa nilai $\mathrm{t}_{\text {hitung }}=1.42<$ nilai $\mathrm{t}_{\text {tabel }}=2.10$, hal ini berarti terjadi penolakan $\mathrm{H}_{0}$ yang berarti ada perbedaan nilai kemampuan komunikasi matematis antara siswa yang menggunakan perlakuan pembelajaran yang berbeda walaupun sama-sama memiliki kreativitas rendah. Selain itu adanya penerimaan $\mathrm{H}_{1}$ berarti kemampuan komunikasi matematis siswa yang diberikan perlakuan dengan menggunakan Model Brain Based Learning lebih rendah dibandingkan siswa yang menggunakan perlakuan Model Ekspositori yang sama-sama memiliki kreativitas rendah.

\section{SIMPULAN}

Berdasarkan temuan yang dilakukan oleh peneliti, maka ditarik kesimpulan bahwa 1) Model Brain Based Learning memberikan pengaruh yang lebih baik terhadap kemampuan komunikasi matematis siswa dibandingkan Model Ekspositori. Hal ini ditunjukkan dengan lebih tingginya kemampuan komunikasi matematis siswa yang diberikan Model Brain Based Learning dibandingkan dengan siswa yang diberikan Model Ekspositori; 2) Terdapat interaksi antara model pembelajaran dan kreativitas siswa terhadap kemampuan komunikasi matematis siswa. Hal ini menunjukkan bahwa kemampuan komunikasi matematis siswa dipengaruhi oleh model pembelajaran dan kreativitas siswa; 3) Model Brain Based Learning memberikan pengaruh yang lebih baik dibandingkan dengan Model Ekspositori terhadap kemampuan komunikasi matematis siswa dengan kreativitas tinggi, karena kemampuan komunikasi matematis pada siswa dengan kreativitas tinggi 
yang diberikan Model Brain Based Learning lebih tinggi dari pada siswa dengan kreativitas tinggi yang diberikan Model Ekspositori; 4) Model Brain Based Learning memberikan pengaruh yang kurang baik dibandingkan dengan Model Ekspositori terhadap kemampuan komunikasi matematis siswa dengan kreativitas rendah, karena kemampuan komunikasi matematis pada siswa dengan kreativitas rendah yang diberikan Model Brain Based Learning lebih rendah dari pada siswa dengan kreativitas tinggi yang diberikan Model Ekspositori.

\section{DAFTAR RUJUKAN}

A. Al-Balushi, K., \& Al-Balushi, S. (2018). Effectiveness of BrainBased Learning for Grade Eight Students' Direct and Postponed Retention in Science. International Journal of Instruction (Vol. 11). https://doi.org/10.12973/iji.2018. $11336 \mathrm{a}$

Abdur Rahman As'ari. (2016). Variasi Kontruk dalam Pembelajaran Matematika. Malang: CV. Bintang Sejarah.

Adiansha, A. A., \& Sumantri, M. S. (2017). The Effect of Brain Based Learning Model and Creative Thinking on the Ability of Mathematics Concept of Elementary Students, 5(12), 1195-1199.

https://doi.org/10.12691/educatio n-5-12-4

Ahmad Susanto. (2013). Teori Belajar \& Pembelajaran di Sekolah Dasar. Jakarta: Prenadamedia Group.
Cai, J., Jakabcsin, M. S., Lane, S. (n.d.). Assessing students' mathematical communication ( $p$. 238). school science and mathematics.

Cockburn, A. D. (2007). Mathematical understanding 5-11: a practical guide to creative communication in mathematics (p. 28). London: Paul Chapman Publishing.

Connell, J. D. (2009). The Global Aspects of Brain-Based Learning. Educational Horizons, 88(1), 2839. Retrieved from http://www.jstor.org/stable/42923 784

Cooke, B. D., \& B. (n.d.). Mathematical communication in the classroom: a teacher makes a difference. Early Childhood Education Journal, Vol. 32. N, 365.

Duman, B. (2010). The Effects of Brain-Based Learning on the Academic Achievement of Students with Different Learning Styles. Educational Sciences: Theory \& Practice, 10(4), 20772103.

Gladys, J., Stella, D., \& Omobolanle, G. (2018). Effect of Brain-based Learning Model on Colleges of Education Students' Retention and Attitude in "Current Electricity" in Taraba State, Nigeria. Journal of Education, Society and Behavioural Science (Vol. 25). https://doi.org/10.9734/JESBS/20 $18 / 40519$

GÖZÜYEŞİL, E., \& DİKİCİ, A. (2014). The Effect of Brain Based Learning on Academic Achievement: A Meta-analytical Study. Educational Sciences: Theory \& Practice, 14(2), 642- 
648.

https://doi.org/10.12738/estp.201 4.2.2103

Heruman. (2012). Model Pembelajaran Matematika di Sekolah Dasar. Bandung: PT Remaja Rosdakarya.

Indonesia, I., Nation, U., Goals, S. D., Indonesia, S., \& Nam, V. (2016). (C) Oecd 2016, 1-8.

Jensen, E. (2007). Brain Based Learning The New Science of Teaching \& Training Revised Edition. Yogyakarta: Pustaka Pelajar.

Kartikaningtyas, V., A Kusmayadi, T., \& Riyadi, R. (2018). The effect of brain based learning with contextual approach viewed from adversity quotient. Journal of Physics: Conference Series (Vol. 1022).

https://doi.org/10.1088/17426596/1022/1/012014

Kebudayaan, P. M. P. dan. (2016). LAMPIRAN PERATURAN MENTERI PENDIDIKAN DAN KEBUDAYAAN NOMOR 21 TAHUN 2016.

Maulani, D., Suyono, Noornia, A. (2017). Pengaruh Penerapan Model Reciprocal Teaching terhadap Kemampuan Komunikasi Matematis ditijau dari Self-concept Siswa di SMAN Kecamatan Tambun Selatan Bekasi, 10(2), 14-24.

Miranda, Z., Cilvia, D., \& Rahman, B. (2015).

KOMUNIKASI MATEMATIS SISWA ( Studi Kuasi Eksperimen Kelas VIII SMPN 2 Pagedangan ), 1, 85-98.

NCES, N. C. for E. S. (2017). Highlights From TIMSS and TIMSS Advanced 2015, 1-58.
Ningsih, M. M. and Y. P. (2017). The Effects of Brain Based Learning Approach on Motivation and Students Achievement in Mathematics Learning. Journal of Physics: Conference Series, 895(1), 12057. Retrieved from http://stacks.iop.org/1742$6596 / 895 / \mathrm{i}=1 / \mathrm{a}=012057$

Ozturk, N. (2018). A Brief Review of Theory and Research on BrainBased Learning.

Permendikbud. (2016). Permendikbud Th. 2016 No. 021 Ttg. Standar Isi Pend. Dasar_ Menengah.pdf.

PISA. (2016). PISA 2015 Results in Focus. Oecd, 16. https://doi.org/10.1787/97892642 66490-en

Schneider, E. \& Peschek, W. (2002). . Computer algebra systems (cas) and mathematical communication. The International Journal of Computer Algebra in Mathematics Education, Vol 9, No, 231.

Syafri, H. (2015). Dimensi Ketiga Berhitung. Bandung: Rizqi Press.

Waree, C. (2017a). An Increasing of Primary School Teachers? Competency in Brain-Based Learning. International Education Studies, 10(3), 176. https://doi.org/10.5539/ies.v10n3 p176

Waree, C. (2017b). An Increasing of Primary School Teachers' Competency in Brain-Based Learning. International Education Studie, Faculty of Education, Suan Sunandha Rajabhat Universitas, Bangkok, Tahiland, Vol 10 No.

Widiana, I. W., Bayu, G. W., \& Jayanta, I. N. L. (2017). 
Pembelajaran Berbasis Otak (Brain Based Learning), Gaya Kognitif Kemampuan Berpikir Kreatif Dan Hasil Belajar Mahasiswa. JPI (Jurnal Pendidikan Indonesia), 6(1), 115. https://doi.org/10.23887/jpiundiksha.v6i1.8562

Yasar, M. D. (2017). Brain Based Learning in Science Education in Turkey: Descriptive Content and Meta Analysis of Dissertations. Journal of Education and Practice, 8(9), 161-168. Retrieved from http://search.ebscohost.com/login .aspx?direct $=$ true $\& \mathrm{db}=$ eric $\& \mathrm{AN}=$
EJ1138832\&site=ehost-live

Yulvinamaesari. (2014). Implementasi Brain Based Learning Dalam Pembelajaran. Prosiding Seminar Nasional, 01, 100-102.

Zaini, A., \& Marsigit, M. (2014). Perbandingan Keefektifan Pembelajaran Matematika dengan Pendekatan Matematika Realistik dan Konvensional Ditinjau dari Kemampuan Penalaran dan Komunikasi Matematik Siswa. Jurnal Riset Pendidikan Matematika, 1(2), 152. https://doi.org/10.21831/jrpm.v1i 2.2672 